\title{
Association of TG/HDL Ratio with Cardiovascular Mortality in Patients Who are on Hemodialysis
}

\author{
Hemodiyalize Giren Son Dönem Böbrek Yetersizliği Hastalarında TG/HDL \\ Oranı ile Kardiyovasküler Ölüm Arasındaki İlişki
}

\author{
Umut Karabulut ${ }^{1}$, (1) Gülay Yılmaz² \\ ${ }^{1}$ Acıbadem International Hospital, Clinic of Cardiology, Istanbul, Turkey \\ ${ }^{2}$ Acıbadem International Hospital, Clinic of Nephrology and Transplantation, Istanbul, Turkey
}

\begin{abstract}
Objective: There is a relation between triglyceride/high-density lipoprotein (TG/HDL) ratio, and cardiovascular and all-cause mortality. No study has been conducted on this relationship in cases with end-stage renal disease who are on hemodialysis in Turkey. Therefore, we aimed to see the relation between TG/HDL ratio and cardiovascular mortality in hemodialysis patients.

Methods: This study included 344 cases who were aged $\geq 18$ years and on hemodialysis. These cases were divided into two groups as cardiovascular death $(n=31)$ and survivors $(n=313)$. Primary endpoint of this study was cardiovascular mortality.

Results: Among 344 patients, $74.1 \%$ were males, and the mean age was $43.7 \pm 12.6$ years. Dialysis duration was 1.1 (3.1) years, and the total follow-up duration was 5.9 (2.9) years. TG/HDL ratio was similar in both groups ( $>>0.05)$. Age [human resource (HR): $1.02,95 \%$ confidence interval (Cl): (1,055-1.09), $p=0.02], \mathrm{HbA} 1 \mathrm{c}$ [HR: 1,292, 95\% Cl: $(1,080-1,546), p=0.05]$, and TG/HDL ratio [HR: 1,078, 95\% Cl: $(1,009-1.51)$, $\mathrm{p}=0.026]$ were independent predictors of cardiovascular mortality. Kaplan-Meier curves revealed that cardiovascular mortality was higher in the group using fenofibrate [p (log-rank) =0.01].

Conclusion: TG/HDL ratio is an inexpensive, simply applicable tool that may predict cardiovascular mortality in hemodialysis patients. Therefore, it may significantly benefit in optimizing cardiovascular risk management and treatment goals in these patients.
\end{abstract}

Keywords: TG/HDL ratio, end-stage renal disease, hemodialysis, cardiovascular mortality

\section{öz}

Amaç: Trigliserit/yüksek yoğunluklu lipoprotein (TG/HDL) oranı ile kardiyovasküler ve tüm nedenlere bağlı ölüm arasında bir ilişki olduğu bilinmektedir. Ülkemizde hemodiyalize giren son dönem böbrek yetersizliği hastalarında bu ilişkiyi inceleyen çalışma yapılmamıştır. Bu nedenle çalışmamızda hemodiyaliz hastalarında TG/HDL oranı ile kardiyovasküler ölüm arasında bulunan ilişkiyi incelemeyi amaçladık.

Gereç ve Yöntem: Çalışmaya 18 yaş ve üzerinde, hemodiyalize giren son dönem böbrek yetersizliği tanısı almış 344 hasta dahil edildi. Hastalar kardiyovasküler sebeplerle ölen $(n=31)$ ve sağ kalan $(n=313)$ hasta olarak ikiye bölündü. Çalışmanın birincil sonlanım noktası kardiyovasküler ölüm idi.

Bulgular: Çalışmaya alınan 343 hastanın $\% 74,1^{\prime}$ i erkek olup, yaş ortalaması 43,7 1212,6 idi Ortalama diyaliz süresi 1,1 $(3,1)$ yıl, toplam takip süresi ise 5,9 (2,9) yıldı. TG/HDL oranı her iki grupta da benzerdi ( $p>0,05)$. Yaş [human kaynak (HR): 1,02 \%95 güven aralığı (Cl): (1.055-1,09), $p=0,02]$, HbA1c [HR: 1.292 \%95 Cl: (1.080-1.546), p=0,05 ] ve TG/HDL oranı [HR: 1.078 \%95 Cl: (1.009-1,51), p=0,026], kardiyovasküler ölümün bağımsız öngörücüleri olarak bulundu. Kaplan-Meier eğrileri, fenofibrat kullanan grupta kardiyovasküler mortalitenin anlamlı olarak daha yüksek olduğunu ortaya koydu [p (log-rank) =0,01]

Sonuç: TG/HDL oranı hemodiyaliz hastalarında kardiyovasküler mortaliteyi öngörebilen ucuz, kolay uygulanabilir bir yöntemdir. Bu nedenle, bu hastaların kardiyovasküler risk yönetiminde ve tedavi hedeflerini optimize etmede önemli bir fayda sağlayacaktır.

Anahtar Kelimeler: TG/HDL oranı, son dönem böbrek yetersizliği, hemodiyaliz, kardiyovasküler ölüm

Address for Correspondence: Umut Karabulut, Acıbadem International Hospital, Clinic of Cardiology, Istanbul, Turkey Phone: +90 5325485805 E-mail: drgulaytastan@hotmail.com ORCID ID: orcid.org/0000-0002-3947-9173 


\section{INTRODUCTION}

Although hemodialysis-related complications gradually decrease in cases with end-stage renal disease (ESRD), mortality rates are still greater than that of the normal population. As expected, a significant proportion of this is cardiovascular mortality (1). As traditional risk factors are inadequate to define cardiovascular outcomes in patients with ESRD, practical, easily applicable, new risk markers are frequently sought in this area (2-4).

Lipid disorder is common in ESRD cases, and triglyceride (TG) level is high and high-density lipoprotein (HDL) level is low (5). Pathophysiologically, high TG levels and low $\mathrm{HDL}$ levels interact during lipid metabolism, and each alone is a risk factor for atherosclerosis. TG/HDL ratio is a practical, validated tool, which better demonstrates this complex interaction in ESRD patients with dyslipidemia (6). It is known that a high TG/HDL ratio is associated with metabolic syndrome, hypertension (HTN), diabetes, and cardiovascular events (7-10). Furthermore, it is proven that there is a significant relationship between TG/HDL ratio and cardiovascular and all-cause mortality $(11,12)$.

Many studies have revealed the relationship between TG/ HDL ratio and cardiovascular events in ESRD patients, but these results have been controversial (13-15). Moreover, no study has been conducted only in cases with ESRD who are on hemodialysis in our country. Therefore, we aimed to see the relation between TG/HDL ratio and cardiovascular mortality in the hemodialysis patients.

\section{METHODS}

This study included patients aged $\geq 18$ years who were undergoing hemodialysis between 2015 and 2020. All the patients were divided into two groups: group 1, cardiovascular death $(n=31)$ and group 2, survivors $(n=313)$.

Patients who were $<18$ years of age, with peritoneal dialysis $(n=23)$, or who died from non-cardiac causes $(n=9)$ were removed from the study. Approval for the study was granted by the University of Health Sciences Turkey, Bakırköy Dr. Sadi Konuk Training and Research Hospital Regional Ethics Committee (no: 2021-14-11, date: 12/07/2021). All the participants' rights were protected, and written informed consent was taken from the patients before the procedures.

Demographic data and laboratory findings of cases were collected from Nephrology Clinic Database. Etiology of ESRD, duration of hemodialysis, and cardiac mortality were recorded. Hemogram, routine biomarkers, and total cholesterol (TC), HDL-C, LDL-C, TG, and non-HDL-C values were recorded. Traditional cardiovascular risk factors, history of cardiovascular disease, and coronary revascularization were recorded along with the use of lipid-lowering drugs.

Fasting blood tests included TC, LDL-C, HDL-C, nonHDL-C, and TG. TG was determined using the enzymatic color method (Biotrol), and TC with the photometric method (Siemens, Dimension EXL 200, Germany). The TG/ HDL ratio was calculated. Primary endpoint of this study was cardiovascular mortality.

\section{Statistical Analysis}

Data were analyzed statistically using SPSS (Version 20 software). We confirmed continuous variables to be normally distributed according to the Kolmogorov-Smirnov test. Demographic, clinical, and laboratory values of the two groups were compared by using a t-test or the Mann-Whitney $\mathrm{U}$ test for continuous variables according to the distribution pattern of the data. Chi-square test or Fischer's Exact test were used to compare the categorical data. Kaplan-Meier survival analysis was conducted for cardiovascular mortality, and log-rank test was used to compare the two curves. Cox proportional hazard regression analysis was applied with cardiovascular mortality assigned as a dependent variable. Covariates with $p$-value $<0.15$ or those which were clinically significant were entered into the multivariate model. For all analyses, a two-sided $p$-value $<0.05$ was considered as statistically significant.

\section{RESULTS}

An evaluation was made of 344 patients, comprising $74.1 \%$ males and $25.9 \%$ females. Mean age was $43.7 \pm 12.6$ years. The group with mortality was older than the survivors' group ( $p>0.001$ ). A history of HTN, diabetes mellitus (DM), or coronary artery disease (CAD) was greater in the nonsurvival group than in the survivors' group $(p=0.034, p<0.001$, $p<0.001$, respectively). Mean hemodialysis duration was similar in both groups $(p=0.615)$ (Table 1).

Fenofibrate usage was greater in the non-survival group than in the survivors' group $(p=0.038)$

Glucose and $\mathrm{HbA} 1 \mathrm{c}$ levels were greater in the non-survival group ( $p<0.001, p=0.002$, respectively). Other laboratory parameters and TG/HDL ratio were similar in two groups ( $p>0.05$ for all). Baseline characteristics and laboratory parameters of the cases are shown in Table 1.

Dialysis duration was 1.1 (3.1) years, and the total follow-up duration was 5.9 (2.9) years. Survivors' group was followedup significantly longer than the non-survival group $(p<0.01)$ (Table 1). 
Table 1. Baseline characteristics and laboratory findings of all the study participants

\begin{tabular}{|c|c|c|c|c|}
\hline Variables & Total $(n=343)$ & Non-mortal $(n=312)$ & Mortal $(n=31)$ & $\mathrm{p}$ \\
\hline Gender (male), n \% & $254(74.1)$ & $229(73.4)$ & $25(80.6)$ & 0.380 \\
\hline Age (years) & $43.7 \pm 12.6$ & $42.9 \pm 12.6$ & $52.0 \pm 10.4$ & $<0.001$ \\
\hline BMI $\left(\mathrm{kg} / \mathrm{m}^{2}\right)$ & $25.2 \pm 4.8$ & $25.1 \pm 4.9$ & $26.1 \pm 3.5$ & 0.271 \\
\hline HTN, n (\%) & $128(37.3)$ & $111(35.6)$ & $17(54.8)$ & 0.034 \\
\hline DM, n (\%) & $81(23.6)$ & $64(20.5)$ & $17(54.8)$ & $<0.001$ \\
\hline Smoking, n (\%) & $42(12.2)$ & $36(11.5)$ & $6(19.4)$ & 0.245 \\
\hline CAD history, n (\%) & $56(16.3)$ & $43(13.8)$ & $13(41.9)$ & $<0.001$ \\
\hline Dialysis duration (years) & $1.1(3.1)$ & $1.1(3.4)$ & $1.1(2.8)$ & 0.615 \\
\hline Follow-up (years) & $5.9(2.9)$ & $6.1(2.7)$ & $2.6(3.6)$ & $<0.001$ \\
\hline \multicolumn{5}{|l|}{ Medications, n (\%) } \\
\hline Fenofibrate & $22(6.4)$ & $17(5.4)$ & $5(16.1)$ & 0.038 \\
\hline Statin & $40(11.7)$ & $35(11.2)$ & $5(16.1)$ & 0.384 \\
\hline \multicolumn{5}{|l|}{ Laboratory findings } \\
\hline BUN (mg/dL) & $54(26)$ & $54.5(26.8)$ & $47(26)$ & 0.085 \\
\hline Creatinine, (mg/dL) & $8.3 \pm 2.9$ & $8.4 \pm 2.9$ & $7.3 \pm 2.8$ & 0.053 \\
\hline Sodium, (mg/dL) & $137.6 \pm 3.3$ & $137.6 \pm 3.4$ & $138.2 \pm 2.5$ & 0.348 \\
\hline Potassium, (mg/dL) & $5.1 \pm 0.8$ & $5.2 \pm 0.8$ & $4.7 \pm 0.7$ & 0.130 \\
\hline Calcium, (mg/dL) & $9.1 \pm 0.9$ & $9.1 \pm 0.9$ & $8.9 \pm 0.8$ & 0.288 \\
\hline Uric acid, (mg/dL) & $5.6 \pm 1.6$ & $5.7 \pm 1.6$ & $5.3 \pm 1.6$ & 0.281 \\
\hline Albumin, (mg/dL) & $4.1 \pm 0.6$ & $4.1 \pm 0.6$ & $4.0 \pm 0.8$ & 0.504 \\
\hline Glucose, (mg/dL) & $91(24)$ & 91 (19) & $108(57)$ & $<0.001$ \\
\hline $\mathrm{HbA} 1 \mathrm{C}$ & $5.7 \pm 1.4$ & $5.6 \pm 1.3$ & $6.8 \pm 1.9$ & 0.002 \\
\hline $\mathrm{TC},(\mathrm{mg} / \mathrm{dL})$ & $188.9 \pm 45.4$ & $187.9 \pm 42.3$ & $199.5 \pm 68.9$ & 0.173 \\
\hline LDL-C, (mg/dL) & $116.9 \pm 36.2$ & $116.8 \pm 35.6$ & $118.3 \pm 42.6$ & 0.827 \\
\hline $\mathrm{HDL}-\mathrm{C},(\mathrm{mg} / \mathrm{dL})$ & $50.9 \pm 16.7$ & $51.1 \pm 16.9$ & $48.6 \pm 15.1$ & 0.425 \\
\hline Triglyceride, (mg/dL) & $158(111)$ & $154.5(111.8)$ & $170(92)$ & 0.251 \\
\hline TG/HDL ratio & $3.2(3.3)$ & $3.9(2.7)$ & $3.5(4.4)$ & 0.237 \\
\hline WBC (x103/uL) & $7.5 \pm 2.3$ & $7.5 \pm 2.3$ & $7.9 \pm 2.7$ & 0.219 \\
\hline $\mathrm{Hb}(\mathrm{g} / \mathrm{dL})$ & $11.5 \pm 1.9$ & $11.4 \pm 1.9$ & $11.5 \pm 1.6$ & 0.788 \\
\hline Platelet (x103/uL) & $219.3 \pm 71.3$ & $218.8 \pm 71$ & $223.9 \pm 75.5$ & 0.706 \\
\hline
\end{tabular}

BMI: Body mass index, HTN: Hypertension, DM: Diabetes mellitus, CAD: Coronary artery disease, TC: Total cholesterol, LDL-C: Low-density lipoprotein cholesterol, HDL-C: High-density lipoprotein cholesterol, TG: Triglyceride, WBC: White blood cell, Hb: Hemoglobin

During the follow-up, deaths due to cardiovascular causes were recorded in a total of 31 patients, of which 19 were due to myocardial infarction, 5 to sudden cardiac death, and 7 to stroke.

Cox regression analysis was performed to determine the predictors of cardiac mortality. Variables found to be significant in univariate analysis or with clinical relevance were included in the multivariate analysis. Age, HTN, DM,
CAD history, fenofibrate usage, creatinine, $\mathrm{HbA} 1 \mathrm{c}, \mathrm{TG}$, and TG/HDL ratio were found to be significant in univariate analysis. $(p<0.001, p=0.026, p=0.001, p=0.015, p=0.035$, $p<0.001, p=0.02, p=0.006$, respectively) (Table 2). Only age [human resource (HR): 1.02, 95\% confidence interval (Cl): (1,055-1.09), $p=0.02]$, HbA1c [HR: 1,292, 95\% Cl: $(1,080-1,546), p=0.05]$, and TG/HDL ratio [HR: 1,078, 95\% $\mathrm{Cl}:(1,009-1.51), p=0.026]$ were independent predictors of cardiovascular mortality (Table 2). 
Table 2. Univariate and multivariate Cox regression analyses for cardiac mortality

\begin{tabular}{|c|c|c|c|c|}
\hline \multirow[t]{2}{*}{ Variables } & \multicolumn{2}{|l|}{ Univariate analysis } & \multicolumn{2}{|l|}{ Multivariate analysis } \\
\hline & OR $(95 \% \mathrm{Cl})$ & $\mathrm{p}$ & $\operatorname{HR}(95 \% \mathrm{Cl})$ & $p$ \\
\hline Sex (male) & $1.316(0.539-3.209)$ & 0.546 & - & - \\
\hline Age (years) & 1.061 (1.028-1.095) & $<0.001$ & $1.020(1.055-1.090)$ & 0.002 \\
\hline BMI & $1.040(0.969-1.116)$ & 0.276 & - & - \\
\hline HTN & $2.240(1.103-4.550)$ & 0.026 & - & - \\
\hline DM & $3.400(1.667-6.934)$ & 0.001 & - & - \\
\hline Smoking & $2.011(0.825-4.905)$ & 0.124 & - & - \\
\hline CAD history & $3.726(1.822-7.623)$ & $<0.001$ & - & - \\
\hline Dialysis duration & $0.982(0.888-1.086)$ & 0.723 & - & - \\
\hline Fenofibrate & $3.284(1.256-8.588)$ & 0.015 & - & - \\
\hline Statin & $1.411(0.541-3.678)$ & 0.481 & - & - \\
\hline BUN (mg/dL) & 1.005 (0.998-1.012) & 0.168 & - & - \\
\hline Creatinine (mg/dL) & $0.856(0.741-0.989)$ & 0.035 & - & - \\
\hline Sodium (mg/dL) & $1.01(0.956-1.156)$ & 0.306 & - & - \\
\hline Potassium (mg/dL) & $0.666(0.423-1.048)$ & 0.079 & - & - \\
\hline Calcium (mg/dL) & $0.738(0.499--1.092)$ & 0.129 & - & - \\
\hline Uric acid (mg/dL) & $0.834(0.661-1.053)$ & 0.128 & - & - \\
\hline Albumin (mg/dL) & $0.637(0.358-1.132)$ & 0.124 & - & - \\
\hline Glucose (mg/dL) & $1.004(0.999-1.008)$ & 0.101 & - & - \\
\hline $\mathrm{HbA} 1 \mathrm{C}$ & 1.395 (1.184-1.643) & $<0.001$ & $1.292(1.080-1.546)$ & 0.005 \\
\hline $\mathrm{TC},(\mathrm{mg} / \mathrm{dL})$ & 1.005 (0.998-1.012) & 0.168 & - & - \\
\hline LDL-C, (mg/dL) & $1.001(0.991-1.011)$ & 0.832 & - & - \\
\hline $\mathrm{HDL}-\mathrm{C},(\mathrm{mg} / \mathrm{dL})$ & $0.988(0.965-1.011)$ & 0.295 & - & - \\
\hline Triglyceride, (mg/dL) & $1.002(1.000-1.003)$ & 0.020 & - & - \\
\hline TG/HDL ratio & 1.087 (1.024-1.155) & 0.006 & $1.078(1.009-1.151)$ & 0.026 \\
\hline WBC (x103/uL) & 1.000 (1.000-1.000) & 0.171 & - & - \\
\hline $\mathrm{Hb}(\mathrm{g} / \mathrm{dL})$ & $1.024(0.841-1.246)$ & 0.814 & - & - \\
\hline Platelet (x103/uL) & $1.000(1.000-1.000)$ & 0.646 & - & - \\
\hline
\end{tabular}

BMI: Body mass index, HTN: Hypertension, DM: Diabetes mellitus, CAD: Coronary artery disease, TC: Total cholesterol, LDL-C: Low-density lipoprotein cholesterol, HDL-C: High-density lipoprotein cholesterol, TG: Triglyceride, WBC: White blood cell, Hb: Hemoglobin, OR: Odds ratio, Cl: Confidence interval

Kaplan-Meier curves showed that cardiovascular mortality was greater in the group using fenofibrate [p (log-rank) $=0.01$ ] (Figure 1).

\section{DISCUSSION}

The findings of this study revealed that TG/HDL ratio is an independent predictor for cardiovascular mortality in hemodialysis cases. As expected, the non-survival group was older, and the rates of HTN, DM, and CAD were higher than in the surviving cases. A remarkable finding in the current study in terms of laboratory findings was that the TG and TG/HDL ratio in the cardiac death group was not different from that of the survivors' group. This was thought to be due to the significantly higher usage of fenofibrate in the non-survival group.

One of the main risk factors for cardiovascular diseases in hemodialysis patients is dyslipidemia, which also contributes to decreased physical capacity and weight 


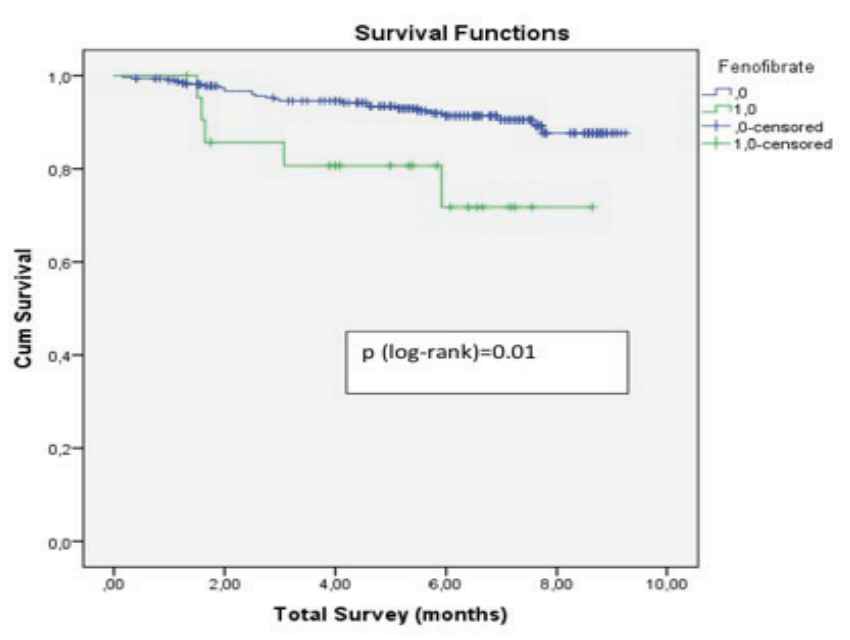

Figure 1. Kaplan-Meier curves revealed that cardiovascular mortality was significantly higher in the group using fenofibrate [p (log-rank) $=0.01]$

loss $(16,17)$. Dyslipidemia is related to many factors such as diabetes, HTN, renal replacement treatment, and drugs used by the hemodialysis patients (18). It is thought that the TG/HDL ratio predicts cardiovascular outcomes better than the measurement of lipid levels alone, since an increase in TG and a decrease in HDL are prominent in these patients (19). Chen et al. (20) showed that high TG/HDL ratio increases the cardiac mortality in patients undergoing both hemodialysis (most of the patients) and peritoneal dialysis, and these results are consistent with those of the current study. Chang et al. (21) published a large-scale study that included only ESRD patients undergoing hemodialysis. Unlike the current study, a significant correlation was seen between a high TG/HDL ratio and low cardiac mortality (21). These conflicting results are attributed to the complex nature of lipid metabolism in dialysis, differences in patient numbers, ethnicity, inclusion criteria, etc. Nevertheless, the mechanism has not been elucidated. In addition to the huge patient population in the study by Chang et al. (21), the results may be considered more valuable due to its prospective design. The results were consistent with those of the current study. The new aspect of this study was the larger number of patients with the advanced renal failure who underwent dialysis. Another remarkable finding in this study was that the survival of the patients using fenofibrate was significantly lower than that in the non-users. This result seems to be the opposite of expectations. The reason for this unexpected result was thought to be that the target TG goals could not be reached in ESRD patients using fenofibrate (due to low dose or irregular use). Many studies have revealed that LDL-C is not a very strong predictor of mortality in hemodialysis patients. There is no significant reduction in cardiovascular mortality with statin (22-24). Therefore, in these cases, TG reduction with aggressive fenofibrate treatment is much more critical.

\section{Study Limitations}

This study was retrospective, single-center, and crosssectional in design. The frequency of dialysis and the medications taken (except lipid drugs) might have affected the cardiac outcomes. The lack of these data could be considered as another limitation.

\section{CONCLUSION}

In conclusion, TG/HDL ratio is an inexpensive, easily applicable tool that may predict cardiac mortality in hemodialysis patients. It will provide significant benefits in optimizing cardiovascular risk management, and treatment goals in these patients. Nevertheless, there is a need for conducting multicenter, prospective, large-scale studies in the future for these results.

\section{ETHICS}

Ethics Committee Approval: Approval for the study was granted by the University of Health Sciences Turkey, Bakırköy Dr. Sadi Konuk Training and Research Hospital Regional Ethics Committee (no: 2021-14-11, date: 12/07/2021).

Informed Consent: Written informed consent was taken from the patients before the procedures.

\section{Authorship Contributions}

Surgical and Medical Practices: G.Y., Concept: U.K., Design: G.Y., Data Collection or Processing: U.K., Analysis or Interpretation: G.Y., Literature Search: U.K., Writing: U.K., G.Y.

Conflict of Interest: No conflict of interest was declared by the authors.

Financial Disclosure: The authors declared that this study received no financial support.

\section{REFERENCES}

1. US Renal Data System: USRDS 2015 Annual Data Report: Atlas of Chronic Kidney Disease and End-Stage Renal Disease in the United States, Bethesda, MD, National Institutes of Health, National Institute of Diabetes and Digestive and Kidney Diseases, 2015.

2. Neuen BL, Leather N, Greenwood AM, Gunnarsson R, Cho Y, Mantha ML. Neutrophil-lymphocyte ratio predicts cardiovascular and all-cause mortality in hemodialysis patients. Ren Fail 2016;38:70-6.

3. Chang YM, Huang YT, Chen IL, Yang CL, Leu SC, Su HL, et al. Heart rate variability as an independent predictor for 8 -year mortality among chronic hemodialysis patients. Sci Rep 2020;10:881.

4. Fitzpatrick J, Sozio SM, Jaar BG, Estrella MM, Segev DL, Parekh $\mathrm{RS}$, et al. Frailty, body composition and the risk of mortality in 
incident hemodialysis patients: the Predictors of Arrhythmic and Cardiovascular Risk in End Stage Renal Disease study. Nephrol Dial Transplant 2019;34:346-54.

5. Ritz E, Wanner C. Lipid abnormalities and cardiovascular risk in renal disease. J Am Soc Nephrol 2008;19:1065-70.

6. Wan K, Zhao J, Huang H, Zhang Q, Chen X, Zeng Z, et al. The association between triglyceride/high-density lipoprotein cholesterol ratio and all-cause mortality in acute coronary syndrome after coronary revascularization. PLoS One 2015;10:e0123521.

7. Moriyama K. Associations Between the Triglyceride to HighDensity Lipoprotein Cholesterol Ratio and Metabolic Syndrome, Insulin Resistance, and Lifestyle Habits in Healthy Japanese. Metab Syndr Relat Disord 2020;18:260-6.

8. Young KA, Maturu A, Lorenzo C, Langefeld CD, Wagenknecht $L E$, Chen $\mathrm{Yl}$, et al. The triglyceride to high-density lipoprotein cholesterol (TG/HDL-C) ratio as a predictor of insulin resistance, $\beta$-cell function, and diabetes in Hispanics and African Americans. J Diabetes Complications 2019;33:118-22.

9. Vega GL, Barlow CE, Grundy SM, Leonard D, DeFina LF. Triglyceride-to-high-density-lipoprotein-cholesterol ratio is an index of heart disease mortality and of incidence of type 2 diabetes mellitus in men. J Investig Med 2014;62:345-9.

10. Yeom H, Kim HC, Lee JM, Jeon Y, Suh I. Triglyceride to high density lipoprotein cholesterol ratio among adolescents is associated with adult hypertension: the Kangwha study. Lipids Health Dis 2018;17:212

11. Bittner V, Johnson BD, Zineh I, Rogers WJ, Vido D, Marroquin OC, et al. The triglyceride/high-density lipoprotein cholesterol ratio predicts all-cause mortality in women with suspected myocardial ischemia: a report from the Women's Ischemia Syndrome Evaluation (WISE). Am Heart J 2009;157:548-55.

12. Caselli C, Rocchiccioli S, Smit JM, Ragusa R, Rosendael R, Buechel, et al., EVINCl, and SMARTool studies, Elevated TG/HDL-C ratio, is an independent predictor of outcome, and it is associated with CAD progression in patients with stable coronary artery disease, European Heart Journal Issue 2020;41:2.

13. Wen J, Chen $Y$, Huang $Y$, Lu $Y$, Liu $X$, Zhou H, et al. Association of the TG/HDL-C and Non-HDL-C/HDL-C Ratios with Chronic Kidney Disease in an Adult Chinese Population. Kidney Blood Press Res 2017:42:1141-54.
14. Kim $Y$, Lee $S$, Lee $Y$, Kang MW, Park S, Park S, et al. Predictive value of triglyceride/high-density lipoprotein cholesterol for major clinical outcomes in advanced chronic kidney disease: a nationwide population-based study. Clin Kidney J 2020;14:1961-8.

15. Sonmez A, Yilmaz MI, Saglam M, Unal HU, Gok M, Cetinkaya $H$, et al. The role of plasma triglyceride/high-density lipoprotein cholesterol ratio to predict cardiovascular outcomes in chronic kidney disease. Lipids Health Dis 2015;14:29.

16. Vaziri ND, Moradi H. Mechanisms of dyslipidemia of chronic renal failure. Hemodial Int 2006;10:1-7.

17. Obi Y, Qader H, Kovesdy CP, Kalantar-Zadeh K. Latest consensus and update on protein-energy wasting in chronic kidney disease. Curr Opin Clin Nutr Metab Care 2015;18:254-62.

18. Moradi H, Vaziri ND. Molecular mechanisms of disorders of lipid metabolism in chronic kidney disease. Front Biosci (Landmark Ed) 2018;23:146-61.

19. Sultani R, Tong DC, Peverelle M, Lee YS, Baradi A, Wilson AM. Elevated Triglycerides to High-Density Lipoprotein Cholesterol (TG/HDL-C) Ratio Predicts Long-Term Mortality in High-Risk Patients. Heart Lung Circ 2020;29:414-21.

20. Chen HY, Tsai WC, Chiu YL, Hsu SP, Pai MF, Yang JY, et al. Triglyceride to high-density lipoprotein cholesterol ratio predicts cardiovascular outcomes in prevalent dialysis patients. Medicine (Baltimore) 2015;94:e619.

21. Chang TI, Streja E, Soohoo M, Kim TW, Rhee CM, Kovesdy CP, et al. Association of Serum Triglyceride to HDL Cholesterol Ratio with All-Cause and Cardiovascular Mortality in Incident Hemodialysis Patients. Clin J Am Soc Nephrol 2017;12:591-602.

22. Tonelli M, Muntner P, Lloyd A, Manns B, Klarenbach S, Pannu N, et al. Association between LDL-C and risk of myocardial infarction in CKD. J Am Soc Nephrol 2013;24:979-86.

23. Wanner C, Krane V, März W, Olschewski M, Mann JF, Ruf G, et al. Atorvastatin in patients with type 2 diabetes mellitus undergoing hemodialysis. N Engl J Med 2005;353:238-48.

24. Fellström BC, Jardine AG, Schmieder RE, Holdaas H, Bannister K, Beutler $\mathrm{J}$, et al. Rosuvastatin and cardiovascular events in patients undergoing hemodialysis. N Engl J Med 2009;360:1395-407. 